\title{
ASSESSING THE IMPACT OF OPERATIONAL RISK MANAGEMENT ON FINANCIAL PERFORMANCE OF SELECTED MAINSTREAM COMMERCIAL BANKS IN CAMEROON
}

\author{
Alain Vilard Ndi Isoh, Ph.D, Egute Mispar Ambang and NCHISE Delphine NCHANG \\ ICT University
}

\begin{abstract}
The Basel Committee for Bank Supervision (BCBS) is aimed at enhancing financial stability of banking system by providing quality supervision and regulatory frameworks for global banking operations. The committee provides recommendations on capital risk, market risk, and operational risk; with the objective of ensuring that financial institutions have adequate capital reserved to absorb unpredicted losses. It is on this premise that this study seeks to analysis the impact of operational risk management strategies on financial performance of selected mainstream commercial banks in Cameroon. A quantitative case study design was used and supported with the philosophical underpins of objectivism ontology and positivism epistemology. Data was primarily sourced using structured questionnaires from two hundred and fifty (250) employees purposively sampled from National Financial Credit Bank (NFCB), the United Bank for Africa (UBA) and Eco Bank from the centre and littoral regions of Cameroon. Data was analysed using Structural Equation Modelling (SEM) with the aid of SPSS 23 and Amos 24. The study revealed that internal operational risk management practices, risk monitoring and control, and training and reporting have significant positive impact on financial performance. This study opined that financial performance increases with the implementation of internal operational risk management strategies. Furthermore, risk monitoring and control have significant mediating impact between training and reporting and financial performance. This study therefore recommends that the provisions of operational risk management strategies as prescribed by the Basel I, II, III and IV accords are significant drivers of a stable and resilient financial system in the case of Cameroon.
\end{abstract}

KEYWORDS: Risk Management; Basel Accords, Operational Risks, Financial Performance; Cameroon

\section{INTRODUCTION}

Risk is inherent to every banking operation. Even the most carefully planned project can run into risk (Bpayne \& Watt, 2019). Many definitions of risk have been advanced (Bpayne \& Watt, 2019; Šti \& Rajić, 2015; Adams, 2014; Halle, 2015). Nonetheless, the most common characteristic of risk is that; it precipitates the feeling of urgency with negative outcomes (Bpayne \& Watt, 2019). Irrespective of its negative feature, risk can be avoided, transfer or accepted (Bpayne \& Watt, 2019). It is imperative to underscore that shareholders' wealth is determined by the trade-offs between risk and return. This explains the view that; higher risk usually implies higher returns (Nghiem, 2015). The expected 
cashflows and return on any investment is highly unknown at the time of the investment chiefly caused by the effects of the time value of money. Banks are exposed to diverse risks including: operational risk, credit risk and market risk (Gangreddiwar, 2015). Credit risk occurs when borrower's default payment of loan, whereas market risk arises from changes in market factors (Gangreddiwar, 2015). On the other hand, operational risk results from the failure of people, system, processes and external events. It is thus necessary to understand operational risk and its effects on the financial performance of commercial banks. (Luburic, 2016)

The impact of operational risk on the financial performance in private commercial banks of Cameroon has emerged as a major issue of concern ((Njimanted, Akume, \& Aquilas, 2017; Valentina Flamini, January 2009)). The 2008 sub-primes crisis was partially attributable to poor operational risk management procedures; which resulted to the closure of many financial institutions such as Lehman Brothers, ENRON and a lot of others. Although studies have been concluded in this area (Lyambiko, 2015; Maalim, 2017), little attention has been directed to the case of the financial markets in Cameroon. This study aimed at examining the impact of operational risk management processes on financial performance of selected mainstream commercial banks in Cameroon with specific interest on: Internal financial monitoring control processes, risk monitoring and control, risk assessment and training and reporting on financial performance.

\section{LITERATURE REVIEW}

\subsection{The Evolution of Commercial Banking in Cameroon and existing regulatory framework}

After independence in the 1960s, the government of Cameroon nationalized the commercial banking sector. The Banque Internationale Pour le Commerce et de L'Industrie du Cameroun (BICIC) was the only state monopoly (Nico Halle \& Co, 2000). The liberalisation of the banking industry led to the institution of Ordinance N0 85/002 of 31/08/1985 establishing credit institutions and loan houses, which was later ratified by Law N0 88/006 of July 1988 and Law N0 90/019 of 10/08/1990 (Nico Halle \&Co. Firm, 2000). These laws annulled the provisions that only Cameroonians could head banking establishments (Nico Halle \& Co, 2000). Since the decree of the 1985 ordinance, constraint on ownership has been removed. The ordinance N0 90/7 of 18/11/1990 of the investment code unlocked investment in the commercial banking sector to all-natural persons or corporate bodies of Cameroonian or foreign nationality regardless of their residence (Nico Halle \& Co, 2000). Nonetheless, the government still own shares in Société Générale des Banques au Cameroon, (SCB), Credit Lyonnais du Cameroun, and Banque International du Cameroun pour l'Epargne et le Credit of the ten banks that existed (Nico Halle \& Co. Firm,2000).

The national laws, the Economic and Monetary Community of Central Africa (CEMAC) law applied by COBAC and the Pan African Organization for the Harmonization of Business Law in Africa 
(OHADA) are the laws that regulate the activities of commercial banks in Cameroon (Nico Halle \& Co. Firm, 2000). The COBAC text of 17/01/1992 harmonise banking regulations in the six-member states of BEAC; differentiating banks from other financial institutions. It makes provisions for the licensing process of financial institutions, the nomination of its executive members and punishes establishments. It also specifies minimum paid-up capital, capital adequacy, risk coverage sharing and liquidity ratios (Nico Halle \& Co. Firm, 2000); whereas, the OHADA Treaty governs conditions for establishing, functioning, and closure of firms in the CFA Zone, (financial \& Co. Firm, 2000).

\subsection{Operation Risk and definitions}

According to (Basel II committee, 2017), Operational risks result from failed procedures, systems or policies such as employee errors, systems failures, fraud or other criminal activity and any event that disrupts business processes. This definition includes legal risk, but excludes strategic and reputational risk. For internal purposes, banks are permitted to contextualize the definition of operational risk, but must take into account the minimum elements as prescribed by Basel Committee's definition. Different from credit risk, market risk, and insurance risk; operational risks are usually not freely incurred. Moreover, they are not diversifiable and cannot be laid off. As long as people, systems, and processes remain imperfect; operational risk cannot be completely eliminated. Operational risk is manageable within some level of risk tolerance. It is natural for organizations to acknowledge that people and processes are likely to incur errors and contribute to ineffective operations.

\subsection{Types of Operational Risk in Commercial banks}

Basel II identified seven types (Categories) of operational risks exposed to financial institutions. Category $\mathrm{I}$ is fraud committed internally in an organization against its interest such as; misappropriation of assets, forgery, bribes, and theft whereas, external frauds (Category II) are committed by third parties including theft, cheque fraud, hacking and acquiring unauthorized information. Category III relates to employment practices and workplace safety risks such as; noncompliance of terms of employment, health-and-safety laws and regulations, inadequate compensation, unethical termination of employments and workplace discrimination. These could precipitate serious financial and reputational damage. Operational risk regarding clients, products and business practice (Category IV) occurs when organizations unintentionally fail to meet promises made to their clients rising from neglectful practices. This takes the forms of privacy and fiduciary breaches, misuse of confidential information, market manipulation, money laundering, unlicensed activities and product defects which may results to legal proceedings.

Another exposure is damages to physical assets (Category V) caused by natural disasters or events like terrorism and vandalism whereas, exposures due to business and systems failures (Category VI) include; supply-chain, telecommunication, and power supply disruptions. All these constitute operational risk. The last category relates to activities comprising; execution, delivery and process 
management (Category VII). Disruptions in supply, transaction and process management have the potential to caused loss. Errors in data entry, miscommunication, deadline failures, accounting errors, inaccurate reports, incorrect client records, and negligent loss of client assets can precipitate legal threats to the organization. Operational risks can be mitigated if the core operational vulnerabilities are known. This could be easily resolved if risk assessment is done daily. Triggers of operational risk evolve periodically. It is incumbent for banks to develop innovative strategies to tackle such risks in other to avoid loss resulting from credibility, reputation and finances of the bank.

\subsection{Bank's Performance Indicators}

Profit is the ultimate goal of any business. However, there are variety of performance indicators used such as; Return on Asset (ROA) and Return on Equity (ROE) (Alexandru, 2008). ROE is a financial ratio that refers to how much profit a company earned compared to the total amount of shareholder equity invested. It is equally referred too as shareholders rewards. A business with high return on equity is more likely to generating cash. ROE reflects the effectiveness and efficacy of bank management (Khrawish, 2011). In addition, return on asset (ROA), also indicates the profitability of a bank. It measures the amount of income generated from the utilisation of assets (Khrawish, 2011). It shows how efficiently resources of the company are used to generate income. Higher ROA indicates efficient utilisation of asset by management Wen (2010).

\section{EMPIRICAL EVIDENCE}

\subsection{Hypothesis Development}

A number of studies have been conducted on operational risk management practices. However, (Yussuf, 2005) examined operational risk management by commercial banks in Kenya and revealed that quantification of risks into various categories was widely practiced though, banks do not necessarily make attempt to predict the degree of occurrence of risks. Meanwhile, (Pourquery \& DeMulder, 2009) found that operational risk management is yet to gain widespread acceptance as an essential component of the business. The survey covered 60 banks from around the world and revealed that about $70 \%$ of 60 banks sampled viewed operational risk as "very important" while, regulatory compliance and fraud are top priorities for operational risk management. Similarly, (Kamau, 2010) in a study on the adaptation of risk management by commercial banks in Kenya, indicated that operational risk is critical and were mainly caused by increase of automated technology, lack of qualified staffs, lack of management supports, and internal and external frauds, whereas, (Macha, 2010), found that 20 out of 56 financial intermediaries have insurance against operational risk in Tanzania. Contrary, Kwasi (2010) revealed evidence of adequate risk management structure supported with strong risk culture in Eco bank Ghana limited. Staffs are conscious about risks and lookout to minimize uncertainty through regular education and training. Koomson (2011) indicates that though operational risk management is new in the Ghanaian banking industry, but their operations are well guided by Basel II directives to cater for operational issues and embrace operational risk management. 
Similarly, (Lyambiko, 2015) revealed that operations risk management positively influenced returns of commercial banks in Tanzania.

\subsection{Basel II Directives}

\subsubsection{Principles for the Assessment of Internal Control Systems}

Principle 1: The board of directors should have responsibility for approving and periodically reviewing overall business strategies and significant policies of the bank; understanding the major risks run by the bank, setting acceptable levels and ensuring that senior management takes the steps necessary to identify, measure, monitor and control these risks. The board is responsible to ensure that adequate and effective system of internal controls are established and maintained.

Principle 2: Senior management are responsibility for implementing strategies and policies approved by the board; developing processes that identify, measure and control risks incurred by the bank. They are charged with maintaining organizational structure that clearly assigns responsibility, authority and reporting framework. Lastly, to ensure that delegated responsibilities are effectively carried out.

Principle 3: The board of directors and senior management are responsible for promoting high ethical and integrity standards, and for establishing a culture within the organization that emphasizes and demonstrates to all levels of personnel the importance of internal controls.

\subsubsection{Risk Recognition and Assessment}

Principle 4: An effective internal control system requires that the material risks that could adversely affect the bank's goals are being recognized and continually assessed. This assessment should cover all risks facing the bank such as credit risk, country and transfer risk, market risk, interest rate risk, liquidity risk, operational risk, legal risk and reputational risk. Internal controls need to address any new risks.

\subsubsection{Control Activities and Segregation of Duties}

Principle 5: Control activities should be integrated in the daily activities of the bank. An effective internal control system requires appropriate control structure to be set up, with well-defined control activities at every business level. These should include: top level reviews; controls for different departments; physical controls; checking for compliance with exposure; a system of approvals and authorizations; and, a system of verification and reconciliation.

Principle 6: An effective internal control system requires that there is appropriate segregation of duties to avoid conflicting responsibilities. Areas of potential conflicts should be identified, and resolved.

\subsubsection{Information and communication}


Principle 7: An effective internal control system requires that there are adequate internal financial, operational and compliance data, as well as external market information about events and conditions that are relevant to decision making. Information should be reliable, timely and accessible.

Principle 8: An effective internal control system requires that there are reliable information systems that cover all significant activities of the bank.

Principle 9: An effective internal control system requires effective channels of communication to ensure that all staff fully adheres to policies and procedures affecting their duties and that relevant information should reach appropriate personnel.

\subsubsection{Monitoring Activities and Correcting Deficiencies}

Principle 10: The overall effectiveness of the bank's internal controls should be monitored on an ongoing basis. Monitoring of key risks should be done daily as well as periodically.

Principle 11: There should be an effective and comprehensive internal audit of the internal control system carried out by trained and competent staff. Reports are sent directly to the board of directors, audit committee, and senior management.

Principle 12: Internal control issues should be reported in a timely manner to the appropriate management level and addressed promptly.

\subsubsection{Evaluation of Internal Control Systems by Supervisory Authorities}

Principle 13: Supervisors should require that all banks, regardless of size, should have an effective system of internal controls that is consistent with the nature, complexity, and risk inherent in their onand off-balance-sheet activities.

Based on the principles of the Basel II accords, the following hypotheses are stated;

H1: Internal operational risk management practices has significant effects on financial performance

H2: Risk assessment and analysis influences financial performance,

H3: Risk monitoring and control significantly effects financial performance

H4: Training and reporting strongly impact financial performance

H5: Risk Identification and understanding is impact financial performance 
Figure 1: Conceptual framework

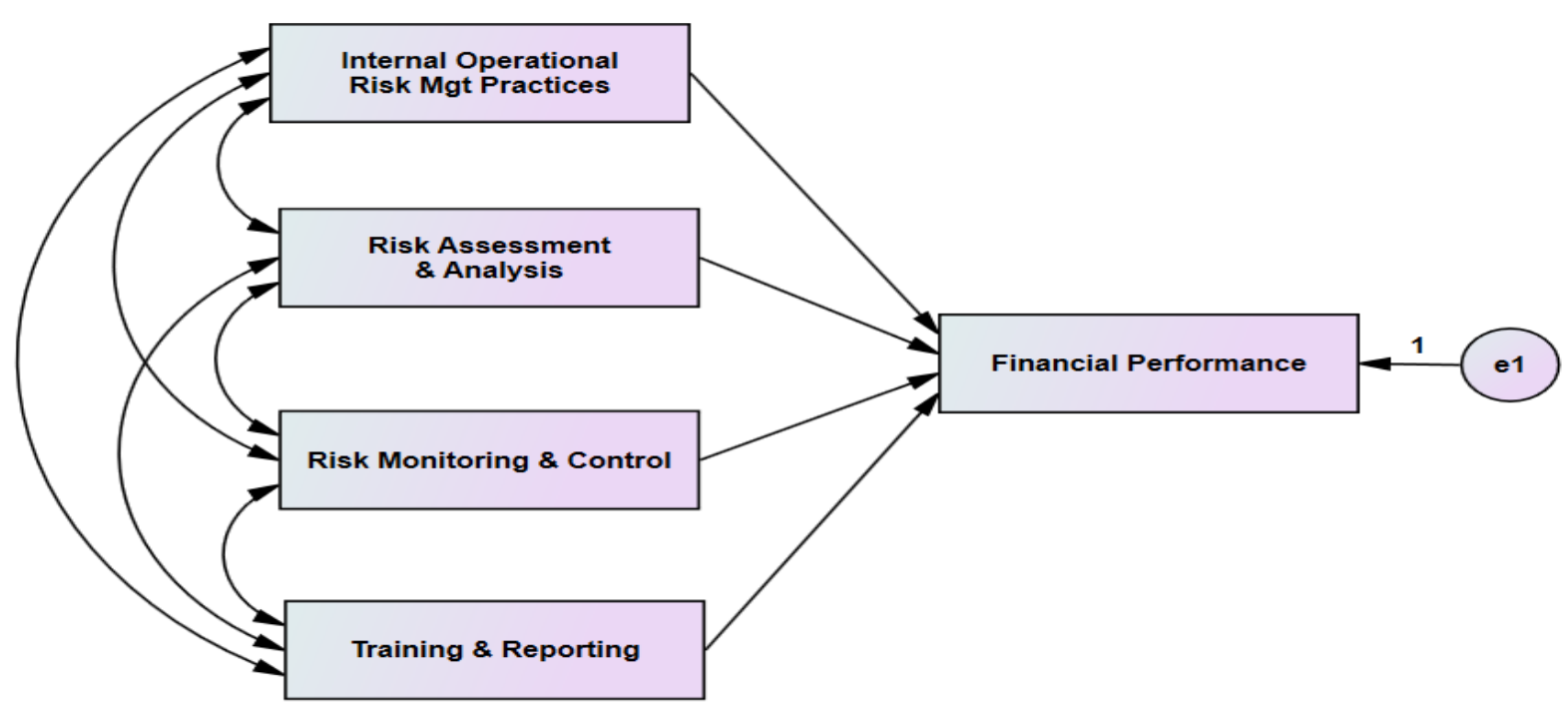

Source: Adapted From Basel I, II, III, IV

\section{METHODOLOGY}

A conclusive case study design (Gomm, Hammersley \& Foster, 2000; Yin, 2009) was adopted and supported by the philosophical orientations of positivism epistemology objectivism ontology (Younkins, 2012; Smith, 2013), and value-free axiology (Khan \& Mubashera, 2012). Data was primarily sourced using structured questionnaires survey (Wiseman-Orr, 2006) and operationalized using five Likert scales (Mogey, 2007). Two hundred and fifty employees were purposively sample from NFC Bank, UBA Bank and Ecobank in the centre and littoral regions of Cameroon. The research approach is deductive (Burneyl, Saleem, \& Hussain, 2008) and the sampling strategy was purposive (Tongco, 2007). Data was analysed using Amos24 and SPSS 23 statistical packages. Parametric assumptions for model fitness (Garson, 2012) were conducted and data cleaned using Exploratory Factor Analysis (Williams, Brown, \& Onsman, 2010) and Confirmatory Factor Analysis (Prudon, 2013). Constructs were tested for validity using the construct validity test (Strauss \& Gregory, 2009). The reliability of the research instrument was completed using alpha Cronbach (Bonett \& Thomas, 2014). Structural Equation Modelling was done based on the goodness of fit parameters supporting the analysis (Joop \& Timo, 1999).

\section{DATA ANALYSIS AND PRESENTATION OF RESULTS}

Data cleaning and management was completed using Exploratory Factor Analysis (EFA). The modalities for analysis were checked. The Kaiser-Meyer-Olkin Measure of Sampling Adequacy $(\mathrm{KMO}=0.703>0.5)$ and the Bartlett's Test of Sphericity with Approx. Chi-Square (X2 = 649.683), Degree of Freedom $(\mathrm{DF}=120)$ and P-Value $(\mathrm{sig}=0.00<0.01 ; 0.05)$ both revealing adequacy of the 
sample size and the existence of at least 1 significant correlation in the data set. Based on these premise, the data was fit for factor analysis. Furthermore, four new components were extracted using Principal Component Analysis (PCA) based on fixed factor extraction mode of 4 items. Total Variance Explained (TVE) was 64.6\%. Components 1, 2, 3, and 4 has Eigen values of 3.942, 2.579, 1.965 and 1.856 respectively all greater than 1 . In addition, they each explained $24.6 \%, 16.1 \%, 12.3 \%$ and $11.6 \%$ of total variance respectively as shown below.

Table 1: Total Variance Explained

\begin{tabular}{|c|c|c|c|c|c|c|c|}
\hline \multirow[b]{2}{*}{ Component } & \multicolumn{3}{|c|}{ Initial Eigenvalues } & \multicolumn{3}{|c|}{ Extraction Sums of Squared Loadings } & \multirow{2}{*}{$\begin{array}{c}\text { Squared Loadings }^{\mathrm{a}} \\
\text { Total } \\
\end{array}$} \\
\hline & Total & $\%$ of Variance & Cumula. \% & \begin{tabular}{|l|} 
Total \\
\end{tabular} & $\%$ of Variance & Cumula \% & \\
\hline 1 & 3.942 & 24.639 & 24.639 & 3.942 & 24.639 & 24.639 & 3.627 \\
\hline 2 & 2.579 & 16.119 & 40.758 & 2.579 & 16.119 & 40.758 & 2.751 \\
\hline 3 & 1.965 & 12.282 & 53.040 & 1.965 & 12.282 & 53.040 & 2.497 \\
\hline 4 & 1.856 & 11.601 & 64.641 & 1.856 & 11.601 & 64.641 & 1.934 \\
\hline 5 & 1.015 & 6.343 & 70.984 & & & & \\
\hline 6 & .717 & 4.483 & 75.468 & & & & \\
\hline 9 & .526 & 3.286 & 86.899 & & & & \\
\hline 10 & .183 & 1.146 & 100.000 & & & & \\
\hline
\end{tabular}

\section{Source: SPSS Outputs}

Furthermore, four fixed components were rotated using Promax and the pattern matrix below showed evidence of appropriate loading of factors for respective components with no cross loading and factor coefficient being less than 0.5 . The extracted and well loaded indicators for each variable then become the retained indicator for the study as shown below.

Table 2: Pattern Matrix

\begin{tabular}{|c|c|c|c|c|}
\hline & 1 & 2 & 3 & 4 \\
\hline IOR1 & & & .743 & \\
\hline IOR2 & & & .765 & \\
\hline IOR3 & & & .716 & \\
\hline IOR7 & & & .731 & \\
\hline RA1 & & & & .584 \\
\hline RA4 & & & & .871 \\
\hline RA5 & & & & .849 \\
\hline RM1 & & .865 & & \\
\hline RM2 & & .642 & & \\
\hline RM3 & & .776 & & \\
\hline RM7 & & .726 & & \\
\hline TR1 & .823 & & & \\
\hline TR2 & .872 & & & \\
\hline TR6 & .737 & & & \\
\hline TR7 & .858 & & & \\
\hline
\end{tabular}




\begin{tabular}{|l|l|l|}
\hline TR8 & \multicolumn{1}{|c|}{.842} & \\
\hline Extraction Method: Principal Component Analysis. & \\
Rotation Method: Promax with Kaiser Normalization. \\
a. Rotation converged in 5 iterations. \\
\hline
\end{tabular}

Source: SPSS Outputs

In addition, data obtained from the dependent variable was downsized using Exploratory Factor Analysis (EFA). Results from the analysis indicated Kaiser-Meyer-Olkin Measure of Sampling Adequacy $(\mathrm{KMO}=0.792>0.5)$ and the Bartlett's Test of Sphericity with Approx. Chi-Square (X2 $=208.756)$, Degree of Freedom $(\mathrm{DF}=15)$ and P-Value (sig $=0.00<0.01 ; 0.05)$ both revealing adequacy of sample size and significant correlation in the data set. Based on these premise the data was fit for factor analysis. Total Variance Explained (TVE) by the extracted components was 70.2\%. Components $1 \& 2$, has Eigen value of 3.171and 1.040 respectively all greater than 1 . In addition, they each explained $52.84 \%$ and $17.33 \%$ of total variance respectively. This is as shown below:

Table 3: Total Variance Explained

\begin{tabular}{|c|c|c|c|c|c|c|c|}
\hline \multicolumn{8}{|c|}{ Total Variance Explained } \\
\hline \multirow[b]{2}{*}{ Component } & \multicolumn{3}{|c|}{ Initial Eigenvalues } & \multicolumn{3}{|c|}{ Extraction Sums of Squared Loadings } & \multirow{2}{*}{\begin{tabular}{|} 
Squared Loadings ${ }^{\mathrm{a}}$ \\
Total
\end{tabular}} \\
\hline & Total & $\%$ of Variance & Cumul. \% & Total & $\%$ of Variance & Cumula \% & \\
\hline 1 & 3.171 & 52.843 & 52.843 & 3.171 & 52.843 & 52.843 & 2.700 \\
\hline 2 & 1.040 & 17.332 & 70.175 & 1.040 & 17.332 & 70.175 & 2.556 \\
\hline 3 & .594 & 9.902 & 80.076 & & & & \\
\hline 4 & .532 & 8.867 & 88.943 & & & & \\
\hline 5 & .355 & 5.917 & 94.861 & & & & \\
\hline 6 & .308 & 5.139 & 100.000 & & & & \\
\hline \multicolumn{8}{|c|}{ Extraction Method: Principal Component Analysis. } \\
\hline When con & & e correlated, sum & squared loadin & annot be ad & ed to obtain a to & variance. & \\
\hline
\end{tabular}

\section{Source: SPSS Outputs}

The pattern matrix below represents factor loadings of the retained indicators for the new component created as shown below:

Table 4: Pattern Matrix

\begin{tabular}{|l|r|r|}
\hline \multicolumn{3}{|c|}{ Pattern Matrix $^{\mathbf{a}}$} \\
\hline & \multicolumn{2}{|c|}{ Component } \\
\cline { 2 - 4 } & 1 & 2 \\
\hline FP1 & & .743 \\
\hline FP2 & & .714 \\
\hline FP4 & .904 & .935 \\
\hline FP5 & .632 & \\
\hline FP6 & .919 & 0.792 \\
\hline FP8 & & 0.000 \\
\hline KMO & & \\
\hline Bartlett's Test of Sphericity & & \\
\hline
\end{tabular}


ISSN 2582-2292

Vol. 2, No. 02; 2020

\begin{tabular}{|l|l|r|}
\hline Variance & 52.843 & 17.332 \\
\hline Total & & 70.175 \\
\hline Extraction Method: Principal Component Analysis. & \\
Rotation Method: Promax with Kaiser Normalization. & \\
\hline a. Rotation converged in 3 iterations. \\
\hline
\end{tabular}

Source: SPSS Outputs

\subsection{Validity and reliability}

All retained indicators and constructs were tested for Construct Validity (CV). The acceptable threshold is when Average Variance Explained (AVE > 0.5) as shown below

Table 5: Construct Validity

\begin{tabular}{|c|c|c|c|c|c|}
\hline Constructs & Indicators & $\begin{array}{r}\text { Factor } \\
\text { Loadings }\end{array}$ & $\begin{array}{r}\text { Squared Of Factor } \\
\text { Loadings }\end{array}$ & Validity - CV & Reliability-CR \\
\hline \multirow{4}{*}{$\begin{array}{l}\text { Internal } \\
\text { operation risk } \\
\text { mgt practices }\end{array}$} & IOR1 & 0.743 & 0.552049 & \multirow[b]{4}{*}{$\mathrm{AVE}=0.55>0.5$} & \multirow[b]{4}{*}{$\mathrm{CR}=0.743>0.6$} \\
\hline & IOR2 & 0.765 & 0.585225 & & \\
\hline & IOR3 & 0.716 & 0.512656 & & \\
\hline & IOR7 & 0.731 & 0.534361 & & \\
\hline \multirow{3}{*}{$\begin{array}{l}\text { Risk assessment } \\
\& \text { analysis }\end{array}$} & RA1 & 0.584 & 0.341056 & \multirow[b]{3}{*}{$\mathrm{AVE}=0.61>0.5$} & \multirow[b]{3}{*}{$\mathrm{CR}=0.675>0.6$} \\
\hline & RA4 & 0.871 & 0.758641 & & \\
\hline & RA5 & 0.849 & 0.720801 & & \\
\hline \multirow{4}{*}{$\begin{array}{l}\text { Risk monitoring } \\
\text { and control }\end{array}$} & RM1 & 0.865 & 0.748225 & \multirow[b]{4}{*}{$\mathrm{AVE}=0.57>0.5$} & \multirow[b]{4}{*}{$\mathrm{CR}=0.78>0.6$} \\
\hline & RM2 & 0.642 & 0.412164 & & \\
\hline & RM3 & 0.776 & 0.602176 & & \\
\hline & RM7 & 0.726 & 0.527076 & & \\
\hline \multirow{5}{*}{$\begin{array}{l}\text { Risk Training } \\
\text { and risk } \\
\text { reporting }\end{array}$} & TR1 & 0.823 & 0.677329 & \multirow[b]{5}{*}{$\mathrm{AVE}=0.69>0.5$} & \multirow[b]{5}{*}{$\mathrm{CR}=0.883>0.6$} \\
\hline & TR2 & 0.872 & 0.760384 & & \\
\hline & TR6 & 0.737 & 0.543169 & & \\
\hline & TR7 & 0.858 & 0.736164 & & \\
\hline & TR8 & 0.842 & 0.708964 & & \\
\hline \multirow{3}{*}{$\begin{array}{l}\text { Financial } \\
\text { Performance }\end{array}$} & FP5 & 0.904 & 0.817216 & \multirow[b]{3}{*}{$\mathrm{AVE}=0.69>0.5$} & \multirow[b]{3}{*}{$\mathrm{CR}=0.79>0.6$} \\
\hline & FP6 & 0.632 & 0.399424 & & \\
\hline & FP8 & 0.919 & 0.844561 & & \\
\hline
\end{tabular}

Source: SPSS Outputs

Furthermore, Confirmatory Factor Analysis (CFA) was completed based on: GFI, CFI, IFI, TLI, RMSEA, SRMR and the Chi-Square goodness of fit parameters. All observed regression paths in the model as shown below are statistically significant:

Figure 2: Confirmatory Factor Analysis 


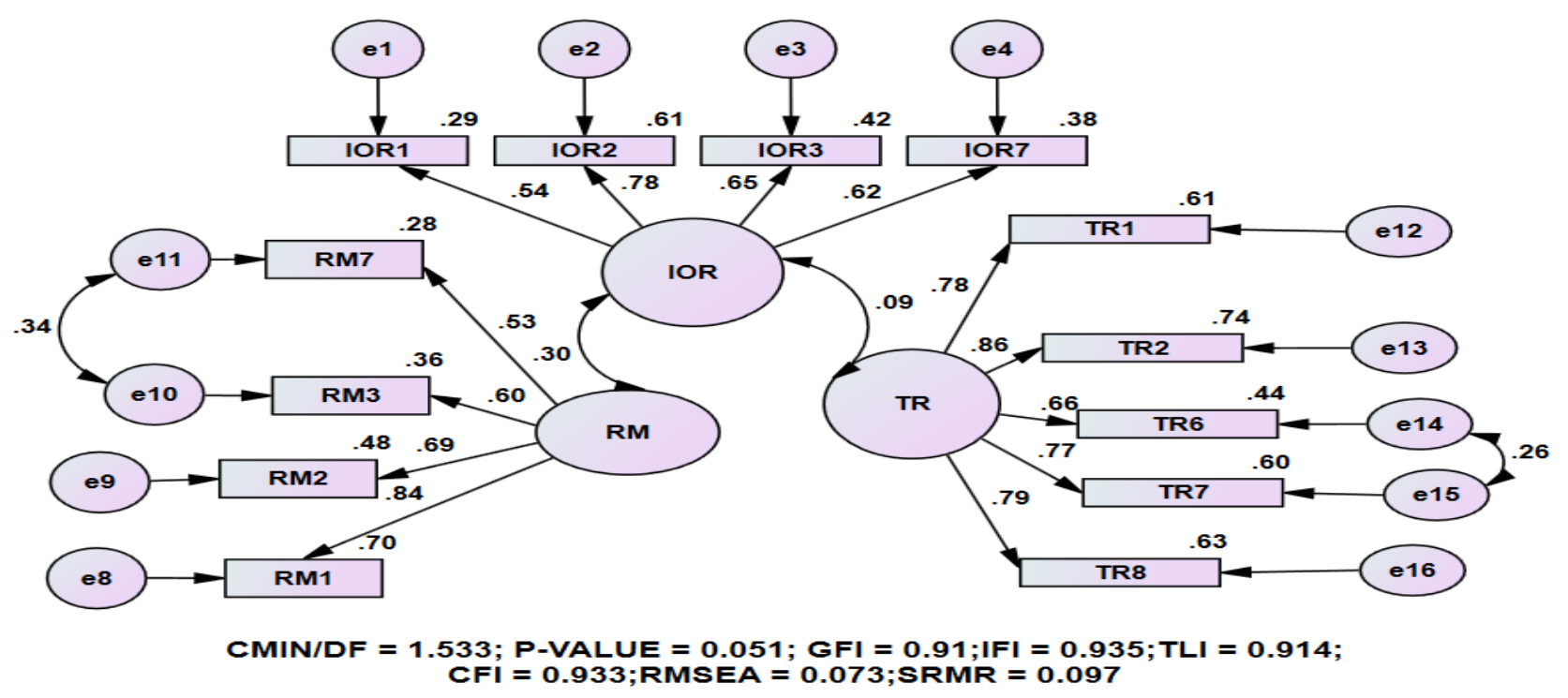

\subsection{Structural Equation Model (SEM) Development and Specifications}

The hypotheses were tested using the specifications of Structural Equation Modelling (SEM) as shown below:

Table 6: Regression Weights: (Group number 1 - Default model)

$\begin{array}{llrrrrr} & & \text { Estimate } & \text { S.E. } & \text { C.R. } & \text { P } & \text { Label } \\ \text { FP_MEAN <--- } & \text { RM_MEAN } & .266 & .137 & 1.939 & .023 & \text { par_1 } \\ \text { FP_MEAN <--- } & \text { TR_MEAN } & .180 & .109 & 1.654 & .038 & \text { par_5 } \\ \text { FP_MEAN <--- } & \text { IOR_MEAN } & .184 & .116 & 1.588 & .011 & \text { par_6 }\end{array}$

Source: SPSS Outputs

The aforementioned model revealed that internal operational risk management practices, risk monitoring and control, and training and reporting have significant positive statistical impact on banks' financial performance. This implies that enhancing operational risk management strategies will results to positive financial outcomes.

Figure 3: Structural Equation Model 


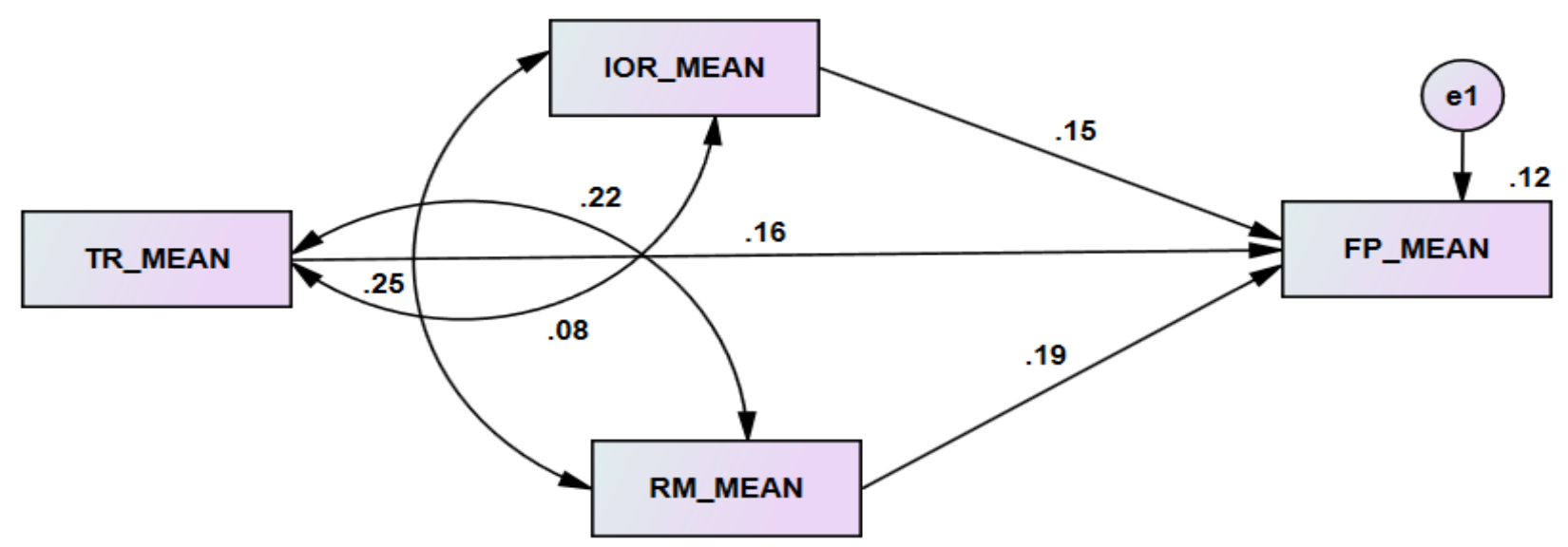

CMIN/DF $=6.752 ; \mathrm{P}$ VALUE $=0.074 ; \mathrm{GFI}=0.941 ; \mathrm{IFI}=0.901 ; \mathrm{TLI}=0.92$ CFI $=0.93$, RMSEA $=0.045$, SRMR $=0.0034$

The study was modified to mediate the effects of risk management and control between the training and reporting and financial performance. The study reviewed positive significant evidence that developing capacity on risk management and control during training has significant impact on financial performance in banks as shown below.

Figure 4: Modified Structural Equation Model

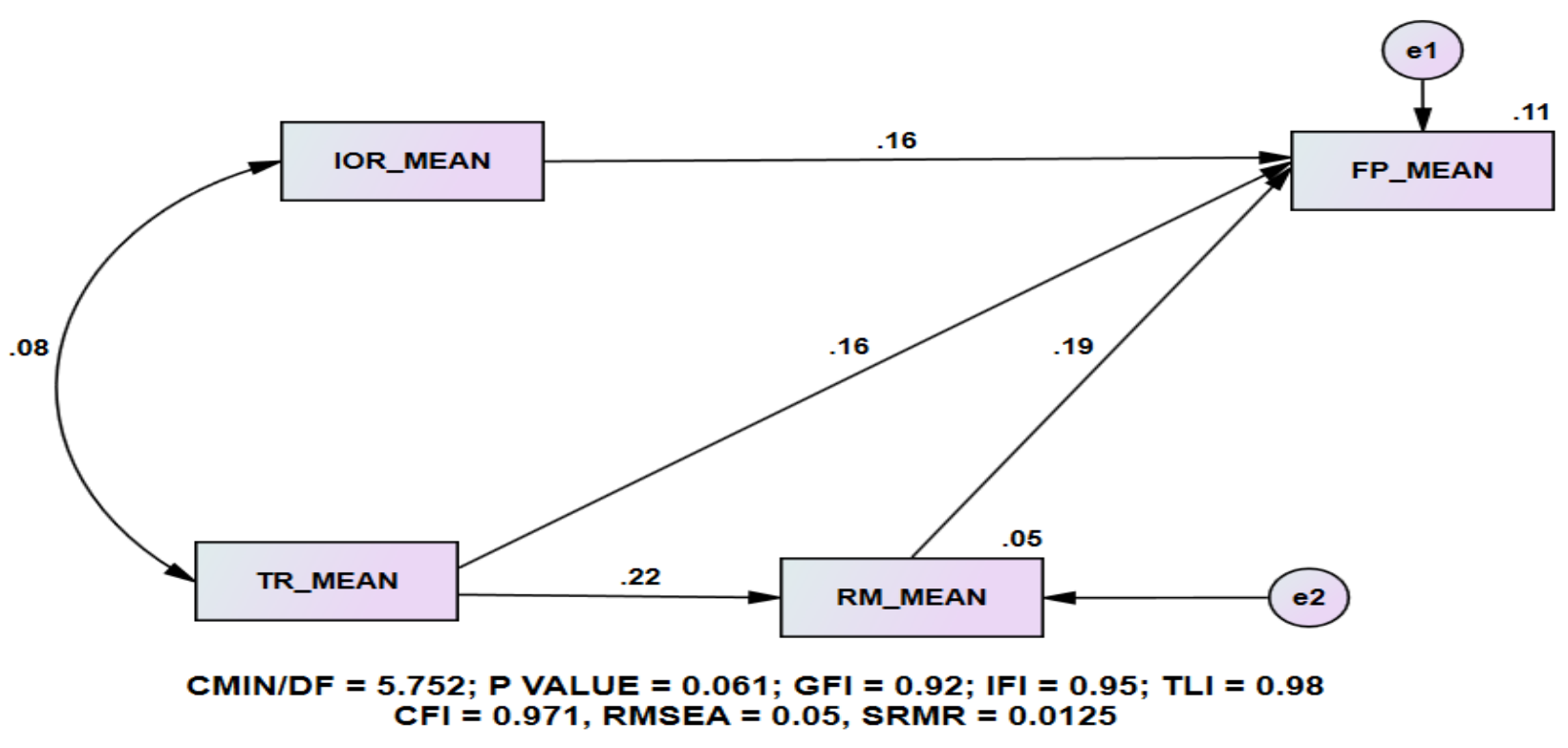


Table 7: Harmonised Test of Hypotheses

\begin{tabular}{|l|l|l|l|}
\hline Hypotheses & $\mathrm{P}-$ Value @ 95\% CI & Size of Effects & Decision /conclusion \\
\hline Internal operational risk management practices & $\mathrm{P}-\mathrm{V}=0.035<0.05$ & 0.15 & Reject the null hypothesis \\
\hline Risk monitoring and control & $\mathrm{P}-\mathrm{V}=0.008<0.05$ & 0.19 & Reject the null hypothesis \\
\hline Training and reporting & $\mathrm{P}-\mathrm{V}=0.01<0.05$ & 0.16 & Reject the null hypothesis \\
\hline $\begin{array}{l}\text { Mediating effect of risk monitoring and control } \\
\text { in the relationship between training and } \\
\text { reporting and financial performance }\end{array}$ & $\mathrm{P}-\mathrm{V}=0.0130<0.05$ & 0.042 & Reject the null hypothesis \\
\hline
\end{tabular}

\section{CONCLUSIONS}

Two key objectives were statistically tested using a sample of 250 employees from NFC, UBA, and Ecobank in Cameroon's economic capital city of doula and Yaoundé to predict the impacts of operational risk management strategies on financial performance. Data was analysed at the 95\% confidence interval using Structural Equation Model and results revealed that internal operational risk management practices, risk monitoring and control, and training and reporting have significant effects on financial performance. The study was modified to mediate the effects of risk management and control between the training and reporting and financial performance. The study reviewed positive significant evidence to suggest that developing capacity of risk management and control during training has significant impact on financial performance of banks. This study therefore recommends the provision of the Basel accords to be relevant in the context of Cameroon banking industry specifically regarding operational risk management.

\section{REFERENCING}

Adams, J. (2014). Managing Risk: framing your problems. BoeringerIngelheim Alumni Seminar, SchlossGracht, 9-11.

Alexandru, C. G. (2008). University Library of Munich, Germany, MPRA.

Atemnkeng, N. a. (2006). Market Structure and Profitability Performance in the Banking Industry of. Retrieved from www.jsd-africa.com: http://www.jsd-africa.com/Jsda/Summer_2006/PDF [

Athanasoglou. (2006). DETERMINANTS OF BANK PROFITABILITY IN THE SOUTH EASTERN EUROPEAN REGION. Muniche Personal RePEc Archive, 01-30.

Basel Committee on Banking supervision. (2001). Principles for the sound Management of Operational RIsk. Basel: Bank For International Settlements.

Bonett, Douglas \& A. Wright, Thomas. (2014). Cronbach's alpha reliability: Interval estimation, hypothesis testing, and sample size planning. Journal of Organizational Behavior.

Bpayne, \& Watt, A. (2019). Project Management . Retrieved 8 16, 2019, from Project Management : https://opentextbc.ca/projectmanagement/chapter/chapter-16-risk-management-planning-projectmanagement/

Burneyl, Saleem, \& Hussain. (2008). Inductive and Deductive Research Approach.

BusinessDictionary. (2019). BusinessDictionary. Retrieved 8 16, 2019, from BusinessDictionary: http://www.businessdictionary.com/definition/risk.html 
Crowe, K. (2009). Liquidity risk management -more important than ever. Harland Financial Solutions, 3.

firm, n. h. (2000). banking in cameroon, an overview. yaounde: 2000.

Flamini, V., McDonald, C., \& Schumacher, L. (2009). The determinants of commercial bank profitability in Sub-sahara Africa. International Monetary Fund Working Paper,.

Gangreddiwar, A. (2015, 9 25). Medici Enabling fin tech scale. Retrieved 8 16, 2019, from Medici Enabling fin tech scale: https://gomedici.com/8-risks-in-the-banking-industry-faced-by-every-bank Garson, G. D. (2012). Testing Statistical Assumptions. Statistical Publishing Associates.

Godfrey Forgha Njimanted, A. D. (2017). Modelling the Impact of Liquidity Trend on the Financial Performance of Commercial Banks and Economic Growth in Cameroon. International Journal of Financial Research, 121-134.

Gul. (2011). Factors Affecting Bank Profitability in Pakistan. Romanian Economic Journal, 61-87. Halle, N. (2015, march). Banking in Cameroon.

Halling M. and Hayden, E. (2006). Bank failure prediction: a two-step survival time approach. C.R.E.D.I.T Conference (p. 31). Vienna: Austrian National Bank.

Holland, J. (2010). "Banks, knowledge and crisis: a case of knowledge and learning. Journal of Financial Regulation and Compliance, 18 (2), 87-105.

Hutchison, e. a. (2007). Cash-To-Cash Analysis And Management: Useful Performance Measures for Improving Profitability. The CPA Journal.

Investment, R. A. (1979, 9). Harvard Business Review. Retrieved 8 16, 2019, from Harvard Business Review: https://hbr.org/1979/09/risk-analysis-in-capital-investment

Jarvis, J. C. (2002). companies, Financial information and the management of small private. Journal of Small Business and Enterprise Development.

Jayadev, S. a. (2009). Are banks sensitive to risk management? The Journal of Risk Finance, 7-22.

Jimmy D. Moss, B. S. (1993). Cash Conversion Cycle And Firm Size: A Study of Retail Firms. Managerial Finance.

Joop, H., \& Timo, B. (1999). An Introduction to Structural Equation Modeling. Family Science Review.

Khan, T., \& Mubashera. (2012). Axiology.

Khrawish, H. (2011). Determinants of commercial Banks performance: Evidence from Jordan. International Research Journal of Finance and Economics.

Luburic, R. (2016, 9). Knowledge and learning in terms of Operational Risk Management in the financial and banking systems. International Journal for Quality Research 10(3):559-568, DOI: 10.18421/IJQR10.03-0, 1-15.

Lyambiko, M. R. (2015). THE EFFECT OF OPERATIONAL RISK MANAGEMENT PRACTICES ON THE FINANCIAL PERFORMANCE IN COMMERCIAL BANKS IN TANZANIA. NAIROBI: UNIVERSITY OF NAIROBI.

Maalim, Y. B. (2017). THE EFFECT OF OPERATIONAL RISK MANAGEMENT PRACTICES 


\section{ON THE FINANCIAL PERFORMANCE IN ISLAMIC BANKS IN KENYA. NAIROBI: University} of Nairobi.

Mogey, N. (2007). "So You Want to Use a Likert Scale?" Learning Technology Dissemination Initiative. http://www.icbl.hw.ac.uk/ltdi/cookbook/info_likert_scale/index.html.

Nghiem, L. (2015). Risk-return relationship: An empirical study of different statistical methods for estimating the Capital Asset Pricing Models (CAPM) and the FamaFrench model for large cap stocks. University of Miami, 1-15.

Nico Halle \& Co. (2000). Banking in Cameroon, an overview. 2000.

Njimanted, G. F., Akume, A. D., \& Aquilas, N. A. (2017). Modelling the Impact of Liquidity Trend on the Financial Performance of Commercial Banks and Economic Growth in Cameroon. International Journal of Financial Research, 8(3), 1-14.

Olweny, T. (2011). EFFECTS OF BANKING SECTORAL FACTORS ON THE PROFITABILITY OF COMMERCIAL BANKS IN KENYA. Economics and Finace Review, 01-30.

Pourquery, P,.\&DeMulder,J. (2009). perationalRiskManagement"TooimportanttoFail”. The Boston consulting Group.

Prudon, P. (2013). Confirmatory factor analysis: a brief introduction and critique.

Rajan, D. W. (2001, April). Liquidity Risk, Liquidity Creation, and Financial Fragility: A Theory of Banking. Journal of Political Economy, 287-327.

Sardakis, G. M. (2007). 'Do liquidity constraints in the first year of trading'. 30th ISBE Conference, International Entrepreneurship, Glasgow,. Glasgow: ISBE Conference, International Entrepreneurship.

Selvam, M. S. (2004). A study on financial health of cement industry-" Z" score analysis. As cited by Farah Naz on the Journal of Teaching and Education, 83-84.

Siminyu, M. M. (2016). Influence of operational risk on Financial Performance of Deposit Taking savings and credit Co-Operatives in Kakamega council. 509-518.

Šoti, A., \& Rajić, R. (2015). The Review of the Definition of Ris. Online Journal of Applied Knowledge Management, 3(3), 17-26.

Strauss, Milton \& T Smith, Gregory. (2009). Construct Validity: Advances in Theory and Methodology. Annual review of clinical psychology.

Tongco, M. D. (2007). Purposive Sampling as a Tool for Informant Selection. A Journal of Plats, People and Applied Research.

Valentina Flamini, C. M. (January 2009). The Determinants of Commercial Bank Profitability in SubSaharan Africa. IMF Working Papers. 09. 10.5089/9781451871623.001.

Williams, B., Brown, T., \& Onsman, A. (2010). Exploratory factor analysis: A five-step guide for novices. Australasian Journal of Paramedicine.

Wiseman-Orr, M. L. (2006). Validation of a structured questionnaire as an instrument to measure chronic pain in dogs on the basis of effects on health-related quality of life.

Yemngang, N. B. (2015). The effect of liquidity risk management Strategy on the financial 
International Journal of Research in Commerce and Management Studies

ISSN 2582-2292

Vol. 2, No. 02; 2020

performance of commercial Banks in Cameroon - Case study: Afriland First Bank. Buea: Pan African Institute For Development - West Africa.

Yussuf. (2005). A survey of Operational Risk Management practices in commercial banks in Kenya. Unpublished paper, University of Nairobi. 